\title{
Herring (Clupea harengus) intake influences lipoproteins but not inflammatory and oxidation markers in overweight men
}

\author{
Helen M. Lindqvist*, Anna Maria Langkilde, Ingrid Undeland and Ann-Sofie Sandberg \\ Division of Food Science, Department of Chemical and Biological Engineering, Chalmers University of Technology, \\ 41296 Göteborg, Sweden
}

(Received 9 January 2008 - Revised 28 April 2008 - Accepted 29 April 2008 - First published online 18 July 2008)

Fish consumption is associated with a lower incidence of CVD and decreases in risk factors for atherosclerosis. Although fish contains other interesting components than fish oil, few studies focus on total fish composition and the influence food preparation might have on health-beneficial components. In the present cross-over intervention study the effect of a 6-week herring diet compared with a reference diet on CVD risk factors was investigated. Thirty-five healthy, but overweight, men (mean BMI $28.3 \mathrm{~kg} / \mathrm{m}^{2}$ ) were randomised to a 6-week herring diet ( $150 \mathrm{~g}$ baked herring fillets/d, $5 \mathrm{~d} /$ week) or a reference diet $(150 \mathrm{~g}$ baked lean pork and chicken fillets/d, $5 \mathrm{~d} /$ week). Diets were switched after a 12-week washout period. Plasma total cholesterol, TAG, HDL, HDL $2, \mathrm{HDL}_{3}$, LDL, C-reactive protein, IL-6, IL-18, intercellular adhesion molecule-1, oxidised LDL, oxygen radical absorbance capacity using perchloric acid $\left(\mathrm{ORAC}_{\mathrm{PCA}}\right)$, whole-blood fatty acids, bleeding time and blood pressure were measured at the beginning and end of each dietary period. HDL was significantly higher after the herring diet period compared with after the reference diet period: $1.04 v .0 .99 \mathrm{mmol} / \mathrm{l}$. TAG decreased after both diets, with no significant difference between the two diets. ORAC $\mathrm{PCA}_{\mathrm{Palues}}$ did not indicate lower concentrations of non-protein plasma antioxidants, and oxidised LDL was not higher after the herring diet than after the reference diet. To conclude, a 6-week herring-rich diet significantly raised HDL compared with a diet of matched lean pork and chicken dishes. No adverse effects on in vivo oxidation or serum antioxidants were found after herring intake.

Fish: $n$-3 Fatty acids: Plasma lipids: Antioxidants

Several recent reviews concluded that the consumption of fish decreases the risk of CHD and coronary heart mortality ${ }^{(1-4)}$. Intervention studies found that fatty fish intake influences several important risk factors for CVD such as blood pressure, TAG, HDL and inflammation ${ }^{(2)}$. These beneficial effects of fatty fish are mainly ascribed to the marine $n$-3 PUFA EPA and DHA, whose effects were demonstrated in numerous studies on fish-oil intake ${ }^{(5)}$. But fish also contain other important nutritional components that may influence the total healthbeneficial outcome. To begin with, fish tissue is rich in endogenous antioxidants. Intake of such antioxidants in a fish meal could theoretically help prevent oxidative stress in the body, caused by the easily oxidised $n-3$ PUFA. The liquid fraction (press juice) from herring was found to prevent oxidation in a food system ${ }^{(6)}$ and to have antioxidative effects in a human monocyte model system $^{(7)}$. Second, fish contains high concentrations of $\mathrm{Se}$, which has been related to a reduced risk of $\mathrm{CVD}^{(8,9)}$. The selenoprotein glutathione peroxidase may reduce accumulation of oxidised LDL in the artery wall ${ }^{(8)}$. Fatty fish is also rich in vitamin $D_{3}$, a key regulator in $\mathrm{Ca}$ homeostasis and bone turnover. Some epidemiological data indicate that osteoporosis is associated with obesity and $\mathrm{CVD}^{(10)}$. Recent studies also suggest that vitamin D is associated with low blood pressure ${ }^{(11)}$ and influences the LDL:HDL ratio beneficially in combination with $\mathrm{Ca}^{(12)}$. Further, fish (cod) proteins have been found to have positive effects on blood pressure, lipoproteins and TAG and to prevent insulin resistance in animal studies ${ }^{(13-19)}$. Fish (salmon) intake has been reported to be much more efficient in increasing serum EPA and DHA than cod liver-oil supplementation, which suggests that EPA and DHA are more easily absorbed when consumed in a fish matrix ${ }^{(20)}$. Harries et al. reported that EPA may be more bioavailable in the short-term from fish than from fish oil capsules, but no difference in EPA and DHA content in erythrocytes or plasma phospholipids was shown after 4 months ${ }^{(21)}$. Although the endogenous levels of the compounds described above differ between fish species, few studies on the intake of a single fish species have been reported.

The composition of the control and background diets and compliance are important issues in dietary intervention studies. Various plant oils are usually used as a control for fish oil, but in fish dietary studies, the control diet is commonly the subject's habitual diet without an intervention meal added. A cross-over design is preferable to avoid interindividual variation and to minimise differences between

Abbreviations: AA, arachidonic acid; FAME, fatty acid methyl esters; ICAM-1, intercellular adhesion molecule-1; ORAC, oxygen radical absorbance capacity; PCA, perchloric acid; RDI, recommended daily intake.

*Corresponding author: Dr Helen Lindqvist, fax +4631 7723830, email helen.lindqvist@chalmers.se 
background diets, but few such studies on fish intake have been reported, and the study participants in these studies prepared the intervention dishes on their own ${ }^{(22-24)}$. Food preparation and choice of side dishes could vary between fish and meat meals and influence outcome, but this is seldom considered in fish dietary studies ${ }^{(25)}$.

The present study evaluates the effects of a diet rich in specified, pre-made herring meals on CVD risk factors in healthy, overweight men. The study was designed to minimise influences of differences in background diets, choice of side dishes, and cooking procedure.

\section{Subjects and methods}

\section{Subjects}

Forty overweight $\left(\mathrm{BMI}>25 \mathrm{~kg} / \mathrm{m}^{2}\right)$ men (mean age 48 years, range 35-60 years) from Volvo Car Corporation (Torslanda, Sweden) volunteered for the study. Table 1 lists their baseline characteristics. None smoked or had high alcohol consumption ( $>$ ten units/week). Subjects were considered eligible if they were healthy, had no chronic or serious disease, and were willing to eat herring once per $\mathrm{d}, 5 \mathrm{~d} /$ week, for 6 weeks. They were considered ineligible if they took blood lipid-lowering or antiinflammatory drugs. None normally ate fish more than three times per week, and they ate no functional food products or other foods with high amounts of long-chain $n$-3 PUFA.

Thirty-five subjects completed the study. Four of these thirtyfive subjects' data were excluded in the TAG analyses due to having breakfast before sampling. For C-reactive protein analyses, eleven subjects were excluded because they suffered from a cold or due to temporary use of anti-inflammatory drugs (ibuprofen). The study was approved by the ethical committee of Sahlgrenska University Hospital (Göteborg, Sweden).

\section{Experimental design}

The study was a randomised, cross-over, intervention study ( $2 \times 6$ weeks), with herring meals for 6 weeks, chicken or lean pork meals for 6 weeks, and a 12-week washout period between the two interventions. The subjects were given ten meals every 2 weeks and instructed to eat one of these meals at lunch or dinner every day, $5 \mathrm{~d}$ per week, and preferably on weekdays. From 2 weeks before the study until the end of the study, the subjects were instructed to follow their normal diet, to exclude functional foods from their diet, to eat a maximum of two fish meals per week (outside of the study meals with herring), and to consume a maximum of two alcohol units/ week. They were also asked to maintain their weight during this 25 -week period, if possible. Body weight was checked at each sampling. The first 6-week study period took place in the spring of 2005 and the second in the autumn. Fasting blood samples were collected before and after each period.

\section{Food preparation}

The herring was caught on two occasions, at the end of February 2005 (North Kattegat sea) and at the beginning of September (South Skagerrak sea; used only for the first half of intervention period 2). Fresh butterfly fillets of herring were delivered from Paul Mattson AB (Ellös, Sweden) the morning after they had been filleted, which was $1-2 \mathrm{~d}$ after the catch. The dorsal fins were removed, and the herring fillets were vacuum-packed flat in plastic bags and frozen with a blast freezer (from about $8^{\circ} \mathrm{C}$ to $-20^{\circ} \mathrm{C}$ in about $30 \mathrm{~min}$ ). Fresh pork fillets were obtained about $3 \mathrm{~d}$ after slaughter (Dalsjöfors or Dalberg slaughterhouses, Sweden) and fresh chicken fillets about $1 \mathrm{~d}$ after slaughter (Mowits Chicken, Trollhättan, Sweden). Both fillet types were delivered from Johan i Hallen (Göteborg, Sweden). Before freezing, the chicken fillets were sliced and the pork fillets were sliced and browned (to prevent the meat from getting dry during subsequent cooking). Herring, chicken, and pork fillets were kept at $-40^{\circ} \mathrm{C}$ until the food was prepared.

The dishes were prepared on four occasions at Micvac AB (Mölndal, Sweden) with the patented 'MicVac method'. Vacuum-packed meat and herring were thawed in a cold water-bath and, together with the other meal constituents (about $430 \mathrm{~g} /$ portion in total), were weighed and placed on a tray. The filled tray was sealed with a film equipped with a purpose-designed valve. The tray was then transported through a microwave tunnel where the product was cooked. Air and steam produced by the cooking ingredients escaped through the valve; after cooking, when the tray had cooled down, the valve closed. The remaining steam condensed and created

Table 1. Baseline characteristics for the thirty-five subjects

(Mean values, standard deviations and ranges)

\begin{tabular}{|c|c|c|c|c|}
\hline Subject characteristics & Mean & SD & Range & Normal range \\
\hline Age (years) & $47 \cdot 8$ & $6 \cdot 1$ & $35-60$ & \\
\hline $\mathrm{BMI}\left(\mathrm{kg} / \mathrm{m}^{2}\right)$ & $28 \cdot 3$ & $2 \cdot 6$ & $24 \cdot 7-34 \cdot 7$ & Overweight $25-30$, obesity $>30$ \\
\hline Weight (kg) & $93 \cdot 5$ & $9 \cdot 8$ & $82-127$ & \\
\hline SS blood pressure $(\mathrm{mmHg})$ & $124 \cdot 9$ & $11 \cdot 7$ & $103-160$ & Normal SS/DS $<120 / 80$, high SS/DS $>140 / 90$ \\
\hline DS blood pressure (mmHg) & $79 \cdot 7$ & 8.5 & $63-100$ & \\
\hline Serum total cholesterol (mmol/l) & $5 \cdot 3$ & 0.79 & $3 \cdot 6-6 \cdot 6$ & Optimal $<5 \cdot 2$, high $>6 \cdot 2$ \\
\hline Serum LDL $(\mathrm{mmol} / \mathrm{l})$ & $3 \cdot 6$ & 0.71 & $2 \cdot 2-4 \cdot 7$ & Optimal $<2 \cdot 6$, high $>4 \cdot 1$ \\
\hline Serum HDL (mmol/l) & $1 \cdot 0$ & 0.18 & $0.7-1 \cdot 4$ & Low $<1.0$ \\
\hline Serum TAG (mmol/l) & 1.6 & 0.74 & $0 \cdot 7-3 \cdot 8$ & Optimal $<1.7$, high $>2 \cdot 3$ \\
\hline Whole-blood AA (g/l) & 0.203 & 0.034 & $0.15-0.29$ & \\
\hline Whole-blood DHA (g/l) & 0.086 & $0 \cdot 018$ & $0.052-0.119$ & \\
\hline Whole-blood EPA (g/l) & 0.035 & 0.010 & $0.019-0.071$ & \\
\hline$(E P A+D H A) / A A$ & 0.615 & $0 \cdot 17$ & $0.33-1.17$ & \\
\hline
\end{tabular}

SS, systolic; DS, diastolic; AA, arachidonic acid. 
an under pressure in the package, which resulted in the final product: a cooked, pasteurised, and vacuum-packed dish.

After cooking, the dishes were further chilled to $2-4^{\circ} \mathrm{C}$ within about $1 \mathrm{~h}$ using a fan cooler. The vacuum-packed food was kept at $4^{\circ} \mathrm{C}$, transported to Volvo Cars Corporation in Torslanda, and then kept in refrigerators at $4^{\circ} \mathrm{C}$. The study participants picked up the meals and kept them until consumption in their own refrigerators (at work or at home) at $4-8^{\circ} \mathrm{C}$. Before eating, they heated the vacuum-packed dish in the microwave oven on full power. A beep from the valve indicated when the food was ready to eat (after 2-4 min).

\section{Dietary intervention}

The dishes contained exactly $150 \mathrm{~g}$ raw herring or $150 \mathrm{~g}$ raw chicken or $130 \mathrm{~g}$ browned pork fillets (weight loss during browning was about $20 \mathrm{~g}$ ). The protein source in the reference meals was chosen to provide as neutral animal protein source as possible. Lean meat was chosen to avoid a higher intake of SFA in the reference diet than in the herring diet. Table 2 describes the eight dishes with herring or chicken/pork fillets that the study participants received. The side dishes were varied as much as possible to avoid monotony and to provide a nutritious diet. A fat mixture was added to the reference meals (chicken and pork) to compensate for their lower fat content compared with the herring meals. The fat mixture contained $30 \%$ rapeseed oil, $30 \%$ sunflower-seed oil and $40 \%$ margarine. It constituted about $25 \%$ saturated, $38 \%$ monounsaturated and $30 \%$ polyunsaturated fat, which is a mixture of SFA, MUFA and PUFA similar to that found in herring. However, the individual fatty acids in the various groups differed.

Average EPA and DHA intake was about $1.2 \mathrm{~g} / \mathrm{d}$ during the herring diet, while the reference diet provided insignificant amounts $(0.04 \mathrm{~g} / \mathrm{d})$. Each of the intervention meals provided about $28 \%$ energy from proteins, $33 \%$ energy from fat and $39 \%$ energy from carbohydrates (about $2100 \mathrm{~kJ} / \mathrm{d}$ ). Apart from the intervention diet, the subjects consumed their normal diet. Compliance was checked by $24 \mathrm{~h}$ dietary recalls and analyses of fatty acid concentrations in whole blood.

\section{Compositional analysis of the food}

Raw herring, pork and chicken were analysed for total lipids and fatty acid composition. Total lipids were extracted with chloroform and methanol according to Lee's procedure ${ }^{(26)}$. Then $2 \mathrm{~g}$ homogeneous and pooled samples were taken from the herring, chicken, and pork minces.
Fatty acid composition was determined in the extracted lipids by converting the fatty acids to methyl esters according to a modification of the method of Lepage \& $\operatorname{Roy}^{(27,28)}$. The extracted lipids were dissolved in toluene, and $2 \mathrm{ml}$ of this extract was transferred to tubes with fluoropolymerlined caps. Acetyl chloride, $2 \mathrm{ml}(10 \%)$, dissolved in methanol was added to the lipid samples. Methylation occurred in tightly closed tubes that were placed in a $70^{\circ} \mathrm{C}$ water-bath for $2 \mathrm{~h}$ and shaken every $30 \mathrm{~min}$. After cooling, $1 \mathrm{ml}$ Milli-Q water and $1 \mathrm{ml}$ petroleum ether were added, and the tubes were shaken and centrifuged mildly $(2500 \mathrm{rpm})$ for $5 \mathrm{~min}$ at room temperature. Then $2 \mathrm{ml}$ of the upper petroleum ether phase was withdrawn and evaporated at $40^{\circ} \mathrm{C}$ under a stream of $\mathrm{N}_{2}$, and the fatty acid residue was redissolved in $400 \mu \mathrm{l}$ isooctane. Fatty acid methyl esters (FAME) were analysed on a Hewlett-Packard 5890 capillary gas chromatograph (Waldbronn, Germany) equipped with a Hewlett-Packard auto-injector 7673 (Waldbronn, Germany) and concentrations determined with a flame ionisation detector. An SPB-5 column $(30 \mathrm{~m} \times 0.25 \mathrm{~mm}, 0.25 \mu \mathrm{m})$ from Supelco (Bellefonte, PA, USA) was used to separate FAME with $\mathrm{H}_{2}$ as the carrier gas. The initial temperature was $180^{\circ} \mathrm{C}$, and it was elevated by $5^{\circ} \mathrm{C} / \mathrm{min}$ until $250^{\circ} \mathrm{C}$. The injection temperature was $300^{\circ} \mathrm{C}$ and the detection temperature $325^{\circ} \mathrm{C}$. Borwin (Le Fontanil, France) evaluation chromatography software was used to evaluate the FAME.

Dry weight was calculated by drying $5 \mathrm{~g}$ muscle samples at $105^{\circ} \mathrm{C}$ until a constant weight was obtained. Protein content was estimated as the difference between wet weight, dry weight and fat content.

Nutritional values of the meals and of the whole diet (from $24 \mathrm{~h}$ recalls) were calculated using a software package (Dietist ${ }^{\circledR}$; Aivo, Bromma, Sweden) based on data from the Swedish National Food Administration. The nutritional composition of herring with respect to total fat, protein, water, vitamins $\mathrm{E}, \mathrm{A}, \mathrm{D}$ and $\mathrm{B}_{12}$ and Se was adjusted after analysing samples from the herring provided in the study, since herring composition varies over the year. The analyses of vitamins A, $\mathrm{D}$ and $\mathrm{B}_{12}$ and Se were performed at the accredited laboratory Analycen (Lidköping, Sweden). Vitamin E was analysed in our laboratory with an HPLC method described in the paper of Sannaveerappa et al. ${ }^{(29)}$.

\section{Blood analysis and bleeding time}

Plasma cholesterol and plasma TAG concentrations were determined using fully enzymic techniques. Plasma HDL

Table 2. The eight different intervention dishes

\begin{tabular}{|c|c|c|c|c|}
\hline Dish & Meat or fish & Starchy side dish & Vegetables & Sauce \\
\hline 1 & Herring or chicken & Pasta & Carrot, onion, mushrooms & Tarragon, garlic, crème fraîche (low-fat), chicken stock \\
\hline 2 & Herring or chicken & Rice & Spinach, red onion & Crème fraîche (low-fat), feta cheese \\
\hline 3 & Herring or chicken & Rice & Tomato, onion, parsley & Chicken stock, garlic, saffron, rapeseed oil \\
\hline 4 & Herring or chicken & Noodles & Pepper, water chestnuts & $\begin{array}{l}\text { Tandoori spices, lime, ginger, lemongrass, sweet and sour } \\
\text { sauce, chicken stock, soya sauce, sesame oil, honey }\end{array}$ \\
\hline 5 & Herring or pork & Pasta & & Canned tomatoes, olive oil, basil, ketchup \\
\hline 7 & Herring or pork & Potatoes & Asparagus & Mustard, crème fraîche (low-fat) \\
\hline 8 & Herring or pork & Rice & $\begin{array}{l}\text { Apple, banana, pepper, } \\
\text { cashew nuts, onion }\end{array}$ & $\begin{array}{l}\text { Curry, coconut milk, chicken stock, apple } \\
\text { juice, red curry paste }\end{array}$ \\
\hline
\end{tabular}


was determined after precipitation of p-apolipoprotein apo B-containing lipoproteins. Precipitation with dextran sulfate was done to separate plasma $\mathrm{HDL}_{2}$ and $\mathrm{HDL}_{3}$ subfractions ${ }^{(30)}$, and plasma LDL-cholesterol was calculated as described by Friedewald et al. ${ }^{(31)}$. These analyses were performed on a Konelab 20 autoanalyser (Thermo Clinical Labsystems, Espoo, Finland). Plasma C-reactive protein was measured by an ultra-sensitive method (Orion Diagnostica, Espoo, Finland). Whole-blood fatty acid composition was determined as FAME by direct methylation of $100 \mu \mathrm{l}$ blood without prior fat extraction. FAME were determined as described above.

Serum concentrations of IL-6 were measured with a highsensitive ELISA, and intercellular adhesion molecule-1 (ICAM-1) concentrations were determined with commercially available ELISA (R\&D Systems Inc., Minneapolis, MN, USA). Oxidised LDL was measured with a sandwich ELISA (Mercodia AB, Uppsala, Sweden) and serum IL-18 with an ELISA method (Medical \& Biological Laboratories Co., Ltd, Nagoya, Japan). Between-assay variation was below $10 \%$ for all assays.

Antioxidative capacity, i.e. hydrophilic antioxidants, in serum was measured with the oxygen radical absorbance capacity $(\mathrm{ORAC})$ assay $^{(32,33)}$ in non-protein serum fractions. Serum samples were treated with $0.5 \mathrm{M}$-perchloric acid (PCA) and centrifuged at $14000 \mathrm{~g}$ for $10 \mathrm{~min}$ at $4^{\circ} \mathrm{C}$ to remove proteins ${ }^{(33)}$. The supernatant fraction was diluted with $75 \mathrm{~mm}$-phosphate buffer $(\mathrm{pH}$ 7.4). The procedure then followed the method described by Davalos et al. ${ }^{(32)}$. Fluorescence was measured every $30 \mathrm{~s}$ for $2 \mathrm{~h}$ in a microplate reader (Safire-II-basic; Tecan, Grödig, Austria). Bleeding time was determined with a Simplate IIR device (Organon Technica, Västra Frölunda, Sweden) according to Mielke ${ }^{(34)}$

All analyses were done at the Wallenberg Laboratory (Sahlgrenska University Hospital, Göteborg, Sweden) except for analyses of food composition and blood fatty acids and the $\mathrm{ORAC}_{\mathrm{PCA}}$ assay, which were done at the Division of Food Science (Department of Chemical and Biological Engineering, Chalmers University of Technology, Göteborg, Sweden).

\section{Statistical methods}

All statistical calculations are comparisons between the two intervention diets made with the paired Student's $t$ test and presented as mean values and standard deviations, with significance set at $P<0 \cdot 05$. Microsoft ${ }^{\circledR}$ Office Excel, 2003, SP2 (Microsoft Corp., Redmond, WA, USA) was used for $t$ test and descriptive statistics. The Statistical Package for the Social Sciences (SPSS, version 14.0 for Windows; SPSS Inc., Chicago, IL, USA) was used for box plots and for testing with the Wilcoxon signed rank test, when a non-normal distribution was expected.

\section{Results}

\section{Diet intake and compliance with dietary instructions}

Table 3 describes the composition of raw herring, chicken and pork. Based on average values, the reference meats (chicken and pork) and the herring had similar contents of fat, protein and water. To compensate for the small difference in total fat content between the reference meals and the herring
Table 3. Composition of the raw herring, chicken and pork meat used in the study

\begin{tabular}{lccccc}
\hline & $\begin{array}{c}\text { Fat } \\
(\%)\end{array}$ & $\begin{array}{c}\text { Water } \\
(\%)\end{array}$ & $\begin{array}{c}\text { Protein } \\
(\%)\end{array}$ & $\begin{array}{c}\text { EPA (\% total } \\
\text { fatty acids) }\end{array}$ & $\begin{array}{c}\text { DHA (\% total } \\
\text { fatty acids) }\end{array}$ \\
\hline Herring (raw) & 5.7 & 76.7 & 17.6 & 6.5 & 12.6 \\
Chicken (raw) & 2.2 & 76.5 & 21.3 & 0.4 & 1.4 \\
Pork (browned) & 6.4 & 70.6 & 23.0 & 0.3 & 0.4 \\
$\begin{array}{c}\text { Chicken + pork } \\
\quad \text { reference }\end{array}$ & 4.3 & 73.6 & 22.2 & 0.4 & 0.9 \\
\hline
\end{tabular}

*Values are averages.

meals, extra fat was added to the chicken meals. Table 3 also illustrates the high EPA and DHA fatty acid content of the herring compared with the chicken and pork.

Results of the $24 \mathrm{~h}$ recalls indicated that the participants followed the dietary instructions. The recalls also indicated lower energy intake during the reference period compared with the herring period, especially on days when a reference meal was eaten. Energy percentages of fat (about $31 \%$ ), protein (about $19 \%$ ) and carbohydrates (about 50\%) were similar during both dietary periods and in the background diet. When no study meals were eaten on weekends, energy intake among the participants varied widely. Compliance in the last weeks of the second study period was somewhat lower and most participants had between one and three dishes left out of thirty of the provided meals when the study ended.

Although the herring was lean $(5.7 \%$ fat $)$ it contained (per $100 \mathrm{~g}$ ) $8.5 \mu \mathrm{g}$ vitamin $\mathrm{D}, 1.04 \mu \mathrm{g}$ vitamin $\mathrm{E}, 12 \mu \mathrm{g} \mathrm{B}$ and $38 \mu \mathrm{g}$ Se. The content of vitamin A was below $21 \mu \mathrm{g} /$ $100 \mathrm{~g}$. The total reported intake of $\mathrm{Ca}$, vitamins $\mathrm{D}$ and $\mathrm{B}_{12}$ and Se was higher after the herring period than after the reference period based on intake reported at the $24 \mathrm{~h}$ recalls. Differences in other minerals and vitamins after the two test periods were non-significant. The $24 \mathrm{~h}$ recalls from the days on herring and background diet (days when no intervention meal was eaten, i.e. days during weekends) showed that these diets provided enough $\mathrm{Ca}$ according to the recommended daily intake $(\mathrm{RDI})^{(35)}$, but the reference diet only provided about half of this $(490 \mathrm{mg} \mathrm{Ca} / \mathrm{d})$. Vitamin $\mathrm{D}(2 \cdot 8 \mu \mathrm{g} / \mathrm{d})$ and Se $(35 \mu \mathrm{g})$ contents in the reference diet were lower than the RDI ( $5 v .50 \mu \mathrm{g} / \mathrm{d})$, but the herring diet provided sufficient amounts; $15.8 \mu \mathrm{g}$ vitamin D/d and $83 \mu \mathrm{g} \mathrm{Se} / \mathrm{d}$. The herring diet also provided $21.2 \mu \mathrm{g}$ vitamin $\mathrm{B}_{12} / \mathrm{d}$ in comparison with the reference diet that just provided about the RDI of vitamin $\mathrm{B}_{12} ; 2.4 \mu \mathrm{g} / \mathrm{d}$. Both intervention diets provided more $\mathrm{Fe}$ and tocopherol than the background diet.

\section{Measurements of whole-blood fatty acids}

The whole-blood (EPA + DHA):arachidonic acid (AA) ratio was measured in each participant, from the start to the end of the herring intervention, and the increase found confirmed that the participants ate the provided food. The increase in (EPA + DHA):AA after the herring diet was independent of whether the herring diet was the first or the second intervention diet. At the start of the study, (EPA + DHA):AA varied between 0.32 and $1.17 \%$ of whole-blood fatty acids, which reflects normal fish consumption and individual variation in whole-blood fatty acids. After the herring intervention, mean 
$(\mathrm{EPA}+\mathrm{DHA}): \mathrm{AA}$ (range $0.34-1.29 \%$ ) was significantly higher compared with after the reference diet (range 0.28$0.89 \%$ ). EPA and DHA percentages were also measured in those individuals with a small increase in (EPA + DHA):AA to ensure that these fatty acids increased after herring intake. Table 3 shows AA, EPA and DHA concentrations in whole blood at baseline and at the end of each dietary period. At the start of both intervention periods, a similar fatty acid ratio was found. EPA and DHA tended to be lower and AA higher after the reference diet. After the herring intervention, EPA and DHA were significantly higher $(P<0 \cdot 00001)$.

Influence of the herring intervention on risk factors or biomarkers for $C V D$

The dietary interventions did not influence body weight. HDL and $\mathrm{HDL}_{2}$ were higher after the herring intervention compared with the reference intervention (Table 4). TAG was reduced in both intervention diets compared with start values (Table 4). None of the other biomarkers were significantly changed, although the oxidised LDL:LDL ratio tended to be lower after the herring period compared with after the reference period.

\section{Discussion}

In the present controlled, cross-over intervention, thirty-five overweight men were provided with and ate herring dishes $5 \mathrm{~d} /$ week for 6 weeks. During the 6 -week control period, the men ate the same dishes but with chicken or lean pork. The herring diet improved HDL compared with the reference

Table 4. Biomarkers and risk factors for CVD

(Mean values and standard deviations for thirty-five men) diet, but no other changes in blood lipids were found The EPA- and DHA-rich herring diet did not result in increased oxidised LDL or decreased antioxidative capacity, which could be due to potent antioxidants from the fish muscle.

\section{Higher HDL after the herring intervention compared with the reference intervention}

The increase in HDL due to herring intake suggests that herring may have important health benefits since low HDL is a well-known risk factor for $\mathrm{CVD}^{(36,37)}$. Average $\mathrm{HDL}$ was $0.99 \mathrm{mmol} / \mathrm{l}$ after the reference diet and $1.04 \mathrm{mmol} / \mathrm{l}$ after the herring diet. In a pilot study where obese subjects (women and men) were given herring and reference meals similar to the ones used in the present study, HDL was higher after the herring dietary period ${ }^{(38)}$. The larger and less atherogenic $\mathrm{HDL}_{2}$-cholesterol was also higher after the herring intervention in the present study. Dietary $n-3$ PUFA were also found to increase $\mathrm{HDL}_{2}$ in previous studies ${ }^{(39,40)}$. Mori et al. compared additions of fish or fish oil to a high-fat ( $40 \%$ energy from fat) and a low-fat diet (30\% energy from fat) and demonstrated that $\mathrm{HDL}$ and $\mathrm{HDL}_{2}$ were higher when fish fatty acids were added. Interestingly, the low-fat diet decreased HDL, but the reduction was counteracted by addition of fish oil ${ }^{(41)}$. This effect might explain why some studies on fish and fish-oil intake show no effect on HDL. Because HDL generally is lower in overweight and obese individuals ${ }^{(42-44)}$, which we also found in our two studies, fish consumption may be beneficial for these individuals, especially for maintaining high HDL during weight reduction.

\begin{tabular}{|c|c|c|c|c|c|c|}
\hline & \multicolumn{2}{|c|}{ Baselineł } & \multicolumn{2}{|c|}{ Reference intervention§ } & \multicolumn{2}{|c|}{ Herring intervention§ } \\
\hline & Mean & SD & Mean & SD & Mean & SD \\
\hline Weight (kg) & 93.5 & $9 \cdot 8$ & $93 \cdot 0$ & $9 \cdot 2$ & $92 \cdot 5$ & $9 \cdot 5$ \\
\hline Whole-blood arachidonic acid (g/l) & 0.203 & 0.034 & 0.207 & 0.034 & $0 \cdot 187^{\star \star \star}$ & 0.029 \\
\hline Whole-blood EPA (g/l) & 0.035 & 0.010 & 0.029 & 0.012 & $0.051^{* * *}$ & 0.015 \\
\hline Whole-blood DHA (g/l) & 0.086 & 0.018 & 0.081 & 0.019 & $0 \cdot 106^{\star * *}$ & 0.022 \\
\hline Systolic blood pressure (mmHg) & $124 \cdot 9$ & $11 \cdot 7$ & $121 \cdot 2$ & $11 \cdot 4$ & $123 \cdot 3$ & $10 \cdot 4$ \\
\hline Diastolic blood pressure $(\mathrm{mmHg})$ & $79 \cdot 7$ & $8 \cdot 5$ & 78.9 & $6 \cdot 1$ & $79 \cdot 7$ & $7 \cdot 6$ \\
\hline TAG $(\mathrm{mmol} / \mathrm{l}) \|$ & 1.58 & 0.74 & $1.29 \dagger$ & 0.51 & $1.23+$ & 0.61 \\
\hline Total cholesterol $(\mathrm{mmol} / \mathrm{l})$ & $5 \cdot 30$ & 0.79 & $5 \cdot 25$ & 0.88 & $5 \cdot 33$ & 0.77 \\
\hline $\mathrm{LDL}(\mathrm{mmol} / \mathrm{l})$ & 3.58 & 0.71 & 3.69 & 0.79 & $3 \cdot 73$ & 0.66 \\
\hline $\mathrm{HDL}(\mathrm{mmol} / \mathrm{l})$ & 1.00 & 0.18 & 0.99 & 0.21 & $1.04^{\star *}$ & 0.23 \\
\hline $\mathrm{HDL}_{2}(\mathrm{mmol} / \mathrm{l})$ & $0 \cdot 24$ & 0.11 & 0.23 & 0.10 & $0.26^{\star *}$ & 0.13 \\
\hline $\mathrm{HDL}_{3}(\mathrm{mmol} / \mathrm{l})$ & 0.76 & 0.13 & 0.76 & 0.13 & 0.77 & 0.17 \\
\hline IL-6 $(\mathrm{pg} / \mathrm{ml})$ & 0.77 & 0.60 & 0.54 & 0.33 & 0.56 & 0.39 \\
\hline IL-18 (pg/ml) & 201 & 82 & 193 & 74 & 188 & 74 \\
\hline ICAM-1 (ng/ml) & 249 & 44 & 236 & 38 & 237 & 36 \\
\hline Oxidised LDL (U/I) & $69 \cdot 4$ & $12 \cdot 0$ & $69 \cdot 4$ & $12 \cdot 2$ & $68 \cdot 8$ & 11.7 \\
\hline $\mathrm{CRP}(\mathrm{mg} / \mathrm{l}) \emptyset$ & 1.94 & 1.00 & 1.91 & 0.89 & 1.86 & 0.97 \\
\hline ORAC $_{\mathrm{PCA}}(\mathrm{mmol}$ Trolox equivalents/l) & $1 \cdot 26$ & 0.11 & 1.31 & $0 \cdot 12$ & $1 \cdot 32$ & 0.10 \\
\hline Bleeding time (s) & 266 & 60 & 251 & 59 & 256 & 56 \\
\hline
\end{tabular}

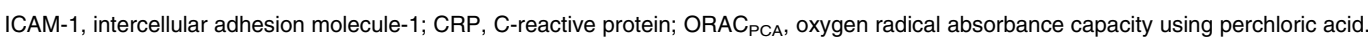
Mean value was significantly different from that for the reference intervention: ${ }^{\star \star} P<0.01,{ }^{\star \star \star} P<0.00001$

t Mean value was significantly different from that at baseline $(P<0.05)$

$\ddagger$ Baseline values were obtained at the start of the study.

$\S$ Intervention values were obtained after 6 weeks of intervention.

$\| n 31$ (Excluding subjects reporting breakfast before sampling).

I $n 24$ (After excluding values $>20$, reported cold or reported intake of acetylsalicylic acid). 
Both intervention diets lowered TAG significantly. This could be due to the high content of protein and fat and low content of carbohydrates (31\% of energy) in both intervention meals ${ }^{(4)}$. The difference in TAG decrease between the diets was non-significant. Thus, the proportions of carbohydrates, proteins and fat in a diet may be more efficient in lowering TAG than an increase in fish intake. Here, choice of control diet is important.

However, numerous studies have found that marine $n$ - 3 PUFA lowers TAG. The minimum intake considered necessary to lower TAG - about $1 \mathrm{~g}$ long-chain $n$-3 PUFA/d - was the amount provided by the herring diet in the present study. Hence, the $n-3$ PUFA in the present study were at the lower limit for expecting a reduction in TAG since the herring was quite lean $\left(5.7 \%\right.$ fat). Seierstad et al. ${ }^{(46)}$ found that TAG was significantly lower after a salmon diet providing EPA and DHA at $2.9 \mathrm{~g} / \mathrm{d}$ but not after a salmon diet providing only $1.5 \mathrm{~g} / \mathrm{d}$. Studies on fish-oil intake concluded that the TAG-lowering effect is not only dose- but also time-dependent ${ }^{(47)}$. A diet that is rich in fatty herring and provides sufficient EPA and DHA for extended periods might be beneficial in maintaining low TAG, but the present study found that the total composition of the diet had a larger impact on TAG.

\section{Blood pressure and bleeding time}

In observational studies, habitual dietary fish intake has been associated with low blood pressure, but few such intervention studies have been published. In the present study, blood pressure was not lower after the herring diet period compared with after the reference period. Bao et al. ${ }^{(48)}$ reported a decrease in blood pressure, while von Houwelingen et al. ${ }^{(49)}$ observed no such effect. The diets in both studies contained about $4 \mathrm{~g}$ EPA and DHA per d.

Studies have reported increases in bleeding time with fatty fish intake ${ }^{(49,50)}$. Other studies have not observed this effect with fish or fish-oil intake ${ }^{(51)}$. We saw no effect on bleeding time, although whole-blood EPA and DHA were significantly higher after the herring than after the reference diet intervention. Von Houwelingen et al. ${ }^{(49)}$ found that bleeding time was significantly longer after 6 weeks - but not after 3 weeks - on a fish diet compared with a control diet. Thus, the effects of longchain $n$-3 PUFA observed in prolonged bleeding time could depend on very high doses and on long treatment periods.

\section{Inflammatory markers and antioxidative capacity}

EPA and DHA have several potent mechanisms for reducing inflammation: increased generation of less inflammatory EPA-derived eicosanoids and decreased generation of AAderived eicosanoids, of inflammatory cytokines such as IL-6 and IL-18, and of adhesion molecules such as ICAM- ${ }^{(52)}$. Thus, a herring-rich diet could theoretically decrease IL-6, IL-18 and ICAM-1. However, none of these markers was lower after herring intake in the present study. Seierstad et al. ${ }^{(46)}$ found lower vascular cell adhesion molecule-1 and IL-6 in patients with CHD after 6 weeks' consumption of tailor-made salmon fed with fish oil (providing $2.9 \mathrm{~g}$ EPA and DHA per d) compared with tailor-made salmon fed with fish oil and rapeseed oil (providing $1.5 \mathrm{~g}$ EPA and DHA per d). ICAM-1 was unaffected. That the subjects in the present study were healthy, although overweight, could explain the lack of effect on inflammatory markers. Studies of fish-oil intake have also reported disparate results concerning vascular adhesion molecules and inflammatory cytokines, which Eschen et al. ${ }^{(53)}$ proposed might be because the effects are sex-, time- and dose-dependent.

Fish oil contains highly unsaturated fatty acids that are easily oxidised. Thus, intake of fish oil could theoretically increase oxidation in the body. However, previous studies have reported diverse results in this field ${ }^{(28,54,55)}$. Serum antioxidative capacity according to the ORAC $\mathrm{PCA}_{\mathrm{PC}}$ assay was not lower after herring intake compared with after the reference diet in the present study. Differences in oxidised LDL between the intervention groups were non-significant. The oxidised LDL:LDL ratio was slightly, but not significantly, lower after the herring diet compared with the reference diet. Studies on $n$-3 PUFA intake have reported varied results on LDL susceptibility to oxidation (oxidation of isolated LDL); some observed no changes, some decreases, and some increases ${ }^{(56)}$. It has also been shown that HDL can protect LDL against oxidation ${ }^{(57)}$. Seierstad et al. ${ }^{(46)}$ observed (1) no effect on circulating oxidised LDL after a salmon diet with $2.9 \mathrm{~g}$ EPA and DHA per $d$ and (2) a small increase in circulating oxidised LDL after a salmon diet with only $1.5 \mathrm{~g} / \mathrm{d}$. These and our own results indicate that fish muscle antioxidants may play an important role in preventing in vivo oxidation.

\section{Intervention meals}

Most study participants ate the study meals at lunch, usually in a lunch restaurant. The portions in the study were small, about $2100 \mathrm{~kJ}$, and energy recommendations for a lunch for men aged 30-60 years are about 3000-4000 kJ. Our choice of a lower-energy meal was to ensure that the participants finished the entire meal. After the first few weeks, when we received a few complaints about portion size, the participants seemed to adapt to the smaller portions or got used to including bread or salad with the meal.

The herring used in the diet provided high amounts of important nutrients such as vitamins $\mathrm{D}$ and $\mathrm{B}_{12}$ and Se in addition to EPA and DHA. Vitamin D insufficiency is not uncommon during winter in Nordic countries since it has to be provided through the diet. The content of vitamin D is negligible in most food, with fatty fish as one exception. The herring diet provided about three times the RDI of vitamin D in comparison with the reference diet that did not even provide the RDI. Since the study was preformed during the summer months this did not cause a vitamin D insufficiency among the study participants. Vitamin D insufficiency has been related to CVD and type 2 diabetes mellitus ${ }^{(58)}$ and an inverse relationship between vitamin $\mathrm{D}$ and the extent of vascular calcification have been found in observational studies in populations with a moderate to high risk for $\mathrm{CHD}^{(59,60)}$. Also Se and vitamin $\mathrm{B}_{12}$ have been linked to CVD. Vitamin $B_{12}$ intake decreases homocysteine. High homocysteine is related to CVD, but studies have so far have failed to show that lowering homocysteine decreases the risk for $\mathrm{CVD}^{(61,62)}$. Se is an essential trace mineral and is a component in glutathione peroxidases. Glutathione peroxidase has been found to reduce hydroperoxides of phospholipids and cholesteryl esters associated with lipoproteins, and could possibly prevent the oxidation of LDL. Prospective epidemiological 
studies on Se status and CVD have mixed findings ${ }^{(8)}$. Thus, including herring in the diet has several possible beneficial effects on cardiovascular health.

\section{Conclusion}

Healthy overweight men had higher HDL, but not lower TAG, when they ate herring dishes for 6 weeks compared with when they ate matched dishes of chicken and lean pork. That TAG was unaffected was probably due to the lower doses of EPA and DHA in the present study compared with many fish-oil studies. Also, addition of herring to the diet, compared with chicken and lean pork, did not influence blood pressure, bleeding time or inflammatory markers. No adverse effects on in vivo oxidation or serum antioxidant status after herring intake were observed. Thus, herring is a good dietary source of EPA and DHA, but also of other important nutrients such as antioxidants, vitamins $\mathrm{D}$ and $\mathrm{B}_{12}$ and Se. Especially overweight or obese subjects, with a low HDL, could benefit from a higher intake of herring.

\section{Acknowledgements}

The present study was supported by Region Västra Götaland, National Board of Fisheries (Dr 223-2451-01), Sweden (European Union Structural Funds) and The Swedish Research Council for Environment, Agricultural Sciences and Spatial Planning (FORMAS) (grant no. 2001-1246).

All authors designed the study. H. M. L. was responsible for planning the diet, meal production, volunteer recruitment, food and plasma analyses, statistical analyses, and in general, the practical realisation of the intervention study. A. M. L. had medical responsibility. H. M. L. interpreted the data and, in collaboration with A.-S. S. and I. U., wrote the manuscript. A. M. L. contributed to the writing of the manuscript. None of the authors has any conflicts of interest.

We would like to thank: Paul Mattsson AB (Ellös, Sweden) which supported and provided the herring fillets; Micvac $\mathrm{AB}$ (Göteborg, Sweden) for the use of their test kitchen and production line; Feelgood $\mathrm{AB}$, for lending us examination rooms; and Amica $\mathrm{AB}$, for help with administrating the food dishes. We also thank Volvo Personvagnar, Torslanda, Sweden, for letting us recruit volunteers among their employees; special thanks to the volunteers. We are grateful to chef Leif Mannerström, who helped us compose tasty recipes, and to Annette Almgren and Britt Holmberg, who were in charge of blood sampling.

\section{References}

1. Konig A, Bouzan C, Cohen JT, Connor WE, Kris-Etherton PM, Gray GM, Lawrence RS, Savitz DA \& Teutsch SM (2005) A quantitative analysis of fish consumption and coronary heart disease mortality. Am J Prev Med 29, 335-346.

2. Undeland I, Ellegard L \& Sandberg A-S (2004) Fish and cardiovascular health. Scand J Nutr 48, 119-130.

3. Burr ML (1993) Fish and ischaemic heart disease. World Rev Nutr Diet 72, 49-60.

4. Psota TL, Gebauer SK \& Kris-Etherton P (2006) Dietary omega-3 fatty acid intake and cardiovascular risk. Am J Cardiol 98, $3 \mathrm{i}-18 \mathrm{i}$.
5. Hooper L, Thompson RL, Harrison RA, et al. (2006) Risks and benefits of omega 3 fats for mortality, cardiovascular disease, and cancer: systematic review. $B M J$ 332, 752-760.

6. Undeland I, Hultin HO \& Richards MP (2003) Aqueous extracts from some muscles inhibit hemoglobin-mediated oxidation of cod muscle membrane lipids. J Agric Food Chem 51, $3111-3119$.

7. Gunnarsson G, Undeland I, Sannaveerappa T, Sandberg AS, Lindgard A, Mattsson-Hulten L \& Soussi B (2006) Inhibitory effect of known antioxidants and of press juice from herring (Clupea harengus) light muscle on the generation of free radicals in human monocytes. J Agric Food Chem 54, 8212-8221.

8. Rayman MP (2000) The importance of selenium to human health. Lancet 356, 233-241.

9. Luong KV \& Nguyen LT (2006) Vitamin D and cardiovascular disease. Curr Med Chem 13, 2443-2447.

10. Richart T, Li Y \& Staessen JA (2007) Renal versus extrarenal activation of vitamin D in relation to atherosclerosis, arterial stiffening, and hypertension. Am J Hypertens 20, 1007-1015.

11. Forman JP, Bischoff-Ferrari HA, Willett WC, Stampfer MJ \& Curhan GC (2005) Vitamin D intake and risk of incident hypertension: results from three large prospective cohort studies. Hypertension 46, 676-682.

12. Major GC, Alarie F, Dore J, Phouttama S \& Tremblay A (2007) Supplementation with calcium + vitamin D enhances the beneficial effect of weight loss on plasma lipid and lipoprotein concentrations. Am J Clin Nutr 85, 54-59.

13. Ait-Yahia D, Madani S, Savelli JL, Prost J, Bouchenak M \& Belleville J (2003) Dietary fish protein lowers blood pressure and alters tissue polyunsaturated fatty acid composition in spontaneously hypertensive rats. Nutrition 19, 342-346.

14. Lavigne C, Tremblay F, Asselin G, Jacques H \& Marette A (2001) Prevention of skeletal muscle insulin resistance by dietary cod protein in high fat-fed rats. Am J Physiol Endocrinol Metab 281, E62-E71.

15. Lavigne C, Marette A \& Jacques H (2000) Cod and soy proteins compared with casein improve glucose tolerance and insulin sensitivity in rats. Am J Physiol Endocrinol Metab 278, E491-E500.

16. Boukortt FO, Girard A, Prost JL, Ait-Yahia D, Bouchenak M \& Belleville J (2004) Fish protein improves the total antioxidant status of streptozotocin-induced diabetes in spontaneously hypertensive rat. Med Sci Monit 10, BR397-BR404.

17. Ait Yahia D, Madani S, Prost J, Bouchenak M \& Belleville J (2005) Fish protein improves blood pressure but alters $\mathrm{HDL}_{2}$ and $\mathrm{HDL}_{3}$ composition and tissue lipoprotein lipase activities in spontaneously hypertensive rats. Eur J Nutr 44, 10-17.

18. Demonty I, Deshaies Y, Lamarche B \& Jacques H (2003) Cod protein lowers the hepatic triglyceride secretion rate in rats. J Nutr 133, 1398-1402.

19. Tremblay F, Lavigne C, Jacques H \& Marette A (2007) Role of dietary proteins and amino acids in the pathogenesis of insulin resistance. Апnи Rev Nutr 27, 293-310.

20. Elvevoll EO, Barstad H, Breimo ES, Brox J, Eilertsen KE, Lund T, Olsen JO \& Osterud B (2006) Enhanced incorporation of $n-3$ fatty acids from fish compared with fish oils. Lipids 41, 1109-1114.

21. Harris WS, Pottala JV, Sands SA \& Jones PG (2007) Comparison of the effects of fish and fish-oil capsules on the $n 3$ fatty acid content of blood cells and plasma phospholipids. Am J Clin Nutr 86, 1621-1625.

22. Beauchesne-Rondeau E, Gascon A, Bergeron J, Jacques H, Noreau L \& Moorjani S (2003) Plasma lipids and lipoproteins in hypercholesterolemic men fed a lipid-lowering diet containing lean beef, lean fish or poultry. Am J Clin Nutr 77, 587-593.

23. Wolmarans P, Benade AJ, Kotze TJ, Daubitzer AK, Marais MP \& Laubscher R (1991) Plasma lipoprotein response to substituting fish for red meat in a diet. Am J Clin Nutr 53, 1171-1176. 
24. Flynn MA, Heine B, Nolph GB, Naumann HD, Parisi E, Ball D, Krause G, Ellersieck M \& Ward SS (1981) Serum lipids in humans fed diets containing beef or fish and poultry. Am J Clin Nutr 34, 2734-2741.

25. Larsen R, Stormo SK, Dragnes BT \& Elvevoll EO (2007) Losses of taurine, creatine, glycine and alanine from cod (Gadus morhua L.) fillet during processing. J Food Compos Anal 20, 396-402.

26. Lee CM, Trevino B \& Chaiyawat M (1996) A simple and rapid solvent extraction method for determining total lipids in fish tissue. J AOAC Int 79, 487-492.

27. Lepage G \& Roy CC (1986) Direct transesterification of all classes of lipids in a one-step reaction. J Lipid Res 27, 114-120.

28. de Ruiz GJ, de Renobales M, del Cerro A, de Fernandes LE, Amiano P, Dorronsoro M \& EPIC Group of Spain E (2002) Habitual fish intake is associated with decreased LDL susceptibility to ex vivo oxidation. Lipids $\mathbf{3 7}, 333-341$.

29. Sannaveerappa T, Sandberg AS \& Undeland I (2007) Evaluation of occasional nonresponse of a washed cod mince model to hemoglobin (Hb)-mediated oxidation. J Agric Food Chem $\mathbf{5 5}, 4429-4435$.

30. Gidez LI \& Miller GJ (1982) Separation and quantitation of subclasses of human plasma high density lipoproteins by a simple precipitation procedure. J Lipid Res 23, 1206-1223.

31. Friedewald WT \& Lecy RI (1972) Estimation of the concentration of low-density lipoprotein cholesterol in plasma, without use of the preparative ultracentrifuge. Clin Chem 18, 499-502.

32. Davalos A, Gomez-Cordoves C \& Bartolome B (2004) Extending applicability of the oxygen radical absorbance capacity (ORAC-fluorescein) assay. J Agric Food Chem 52, 48-54.

33. Ou B, Hampsch-Woodill M \& Prior RL (2001) Development and validation of an improved oxygen radical absorbance capacity assay using fluorescein as the fluorescent probe. J Agric Food Chem 49, 4619-4626.

34. Mielke CH (1984) Measurement of the bleeding time. Thromb Haemost 52, 210-211.

35. National Food Administration (2004) Svenska Näringsrekommendationer (Swedish Dietary Recommendations), 4th ed. Stockholm: Livsmedelsverket.

36. Gordon T \& Castelli WP (1977) High density lipoprotein as a protective factor against coronary heart disease - the Framingham study. Am J Med 62, 707-714.

37. Miller GJ \& Miller NJ (1975) Plasma high-density lipoprotein concentration and the development of ischemic heart disease. Lancet i, 16-19.

38. Lindqvist $\mathrm{H}$, Langkilde $\mathrm{AM}$, Undeland $\mathrm{I}$, Radendal $\mathrm{T}$ \& Sandberg AS (2007) Herring (Clupea harengus) supplemented diet influences risk factors for CVD in overweight subjects. Eur J Clin Nutr 31, 31.

39. Schmidt EB, Skou HA, Christensen JH \& Dyerberg J (2000) $n-3$ Fatty acids from fish and coronary artery disease: implications for public health. Public Health Nutr 3, 91-98.

40. Tholstrup T, Hellgren LI, Petersen M, Basu S, Straarup EM, Schnohr P \& Sandstrom B (2004) A solid dietary fat containing fish oil redistributes lipoprotein subclasses without increasing oxidative stress in men. $J$ Nutr 134, 1051-1057.

41. Mori TA, Vandongen R, Beilin LJ, Burke V, Morris J \& Ritchie J (1994) Effects of varying dietary fat, fish, and fish oils on blood lipids in a randomized controlled trial in men at risk of heart disease. Am J Clin Nutr 59, 1060-1068.

42. Howard BV, Ruotolo G \& Robbins DC (2003) Obesity and dyslipidemia. Endocrinol Metab Clin North Am 32, 855-867.

43. Miller WM, Nori-Janosz KE, Lillystone M, Yanez J \& McCullough PA (2005) Obesity and lipids. Curr Cardiol Rep 7, 465-470.

44. Angelopoulos TJ (2006) Obesity, lipoproteins, and exercise. In Lipid Metabolism and Health, pp. 173-179 [RJ Moffatt and B Stamford, editors]. Boca Rayton, FL: Taylor and Francis.
45. Hilpert KF, Griel AE, Psota $\mathrm{T}$, Gebauer $\mathrm{S}$, Coa $\mathrm{Y}$ \& Kris-Etherton PM (2006) New insights on the role of lipids and lipoproteins in cardiovascular disease: the modulation effects of nutrition. In Lipid Metabolism and Health, pp. 211-248 [RJ Moffatt and B Stamford, editors]. Boca Raton, FL: Taylor and Francis.

46. Seierstad SL, Seljeflot I, Johansen O, Hansen R, Haugen M, Rosenlund G, Froyland L \& Arnesen H (2005) Dietary intake of differently fed salmon; the influence on markers of human atherosclerosis. Eur J Clin Invest 35, 52-59.

47. Milte CM, Coates AM, Buckley JD, Hill AM \& Howe PR (2007) Dose-dependent effects of docosahexaenoic acid-rich fish oil on erythrocyte docosahexaenoic acid and blood lipid levels. Br J Nutr 31, 1-6.

48. Bao DQ, Mori TA, Burke V, Puddey IB \& Beilin LJ (1998) Effects of dietary fish and weight reduction on ambulatory blood pressure in overweight hypertensives. Hypertension 32, $710-717$.

49. von Houwelingen R, Nordøy A, van der Beek E, Houtsmuller U, de Metz M \& Hornstra G (1987) Effect of a moderate fish intake on blood pressure, bleeding time, hematology, and clinical chemistry in healthy males. Am J Clin Nutr 46, 424-436.

50. Thorngren M (1983) Dietary fish and haemostasis, indications of anti-thrombotic properties. PhD Thesis. Lund, Sweden: Lund Universityal Hospital.

51. Blonk MC, Bilo HJ, Nauta JJ, Popp-Snijders C, Mulder C \& Donker AJ (1990) Dose-response effects of fish-oil supplementation in healthy volunteers. Am J Clin Nutr 52, 120-127.

52. Calder PC (2006) n-3 Polyunsaturated fatty acids, inflammation, and inflammatory diseases. Am J Clin Nutr 83, 1505S-1519S.

53. Eschen O, Christensen JH, De Caterina R \& Schmidt EB (2004) Soluble adhesion molecules in healthy subjects: a doseresponse study using $n-3$ fatty acids. Nutr Metab Cardiovasc Dis 14, 180-185.

54. Wolmarans P, Labadarios D, Benade AJ, Kotze TJ \& Luow ME (1993) The influence of consuming fatty fish instead of red meat on plasma levels of vitamins A, C and E. Eur J Clin Nutr 47, 97-103.

55. Anttolainen M, Valsta LM, Alfthan G, Kleemola P, Salminen I \& Tamminen M (1996) Effect of extreme fish consumption on dietary and plasma antioxidant levels and fatty acid composition. Eur J Clin Nutr 50, 741-746.

56. Lapointe A, Couillard C \& Lemieux S (2006) Effects of dietary factors on oxidation of low-density lipoprotein particles. $J$ Nutr Biochem 17, 645-658.

57. Kontush A, de Faria EC, Chantepie S \& Chapman MJ (2005) A normotriglyceridemic, low HDL-cholesterol phenotype is characterised by elevated oxidative stress and HDL particles with attenuated antioxidative activity. Atherosclerosis 182, 277-285.

58. Zittermann A (2006) Vitamin D and disease prevention with special reference to cardiovascular disease. Prog Biophys Mol Biol 92, 39-48.

59. Watson KE, Abrolat ML, Malone LL, Hoeg JM, Doherty T, Detrano R \& Demer LL (1997) Active serum vitamin D levels are inversely correlated with coronary calcification. Circulation 96, 1755-1760.

60. Pittas AG, Lau J, Hu FB \& Dawson-Hughes B (2007) The role of vitamin $\mathrm{D}$ and calcium in type 2 diabetes. A systematic review and meta-analysis. J Clin Endocrinol Metab 92, 2017-2029.

61. Wierzbicki AS (2007) Homocysteine and cardiovascular disease: a review of the evidence. Diab Vasc Dis Res 4, 143-150.

62. Clarke R, Lewington S, Sherliker P \& Armitage J (2007) Effects of B-vitamins on plasma homocysteine concentrations and on risk of cardiovascular disease and dementia. Curr Opin Clin Nutr Metab Care 10, 32-39. 